\section{A Taql polymorphism in the human NF1 gene}

\author{
W.Xu, L.Liu, M.Ponder and B.A.J.Ponder \\ CRC Human Cancer Genetics Group, Department of \\ Pathology, University of Cambridge, Tennis Court Road, \\ Cambridge CB2 1QP, UK
}

Source and Description: A 193 bp cDNA fragment corresponding to exon 4 of the published cDNA sequence (1) for the human NF1 gene was amplified by PCR using 5'-ATAATTGTTGATGTGATTTTCATTG as forward primer and 5'-AATTTTGAACCAGATGAAGAG as reverse primers. This cDNA was used as a probe for hybridization of southern blots made from human DNA samples.

Polymorphism: TaqI digestion yields two bands of $7.0 \mathrm{~kb}$ and $6.5 \mathrm{~kb}$ without constant band.

Frequency: Studied in a total of 40 unrelated Caucasians (20 males and 20 females)

B1 $7.0 \mathrm{~kb}$ allele: 0.4

B2 $6.5 \mathrm{~kb}$ allele: 0.6

Frequency of heterozygosity: 0.48 .

Not Polymorphic For: EcoRI, PstI, PvuII in 10 unrelated Caucasians.

Chromosomal Localization: Assigned to 17q11 within NF1 gene (1).

Mendelian Inheritance: Co-dominant segregation of the TaqI RFLP was observed in two informative von Recklinghausen Neurofibromatosis (NF-1) families (10 meioses). Cosegregation with the NF-1 phenotype was observed in all these families.

Probe Availability: contact W.Xu.

Acknowledgement: This work was supported by LINK, the UK Neurofibromatosis Association.

Reference: 1) Cawthon,R.M. et al. (1990) Cell 62, 193-201.

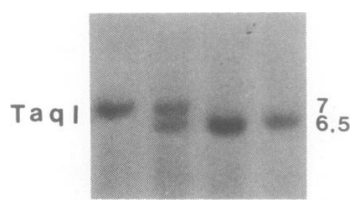

PCR detection of a repeat polymorphism within the F7 gene

G.Marchetti, D.Gemmati ${ }^{1}$, P.Patracchini, M.Pinotti and F.Bernardi *

Centro di Studi Biochimici delle Patologie del Genoma Umano, Istituto Chim. Biol. and 'Istituto Emat e Fisopat Emost, Università di Ferrara, Via L.Borsari 46, 1-44100 Ferrara, Italy

The human coagulation factor VII gene (F7) contains five regions of tandem repeats, four located in introns and one in an untranslated portion of the exon 8 (1). The presence of six or eight copies of a monomer repeat element has been reported in two clones of the FVII gene (2).

PCR amplification of FVII gene regions containing repeated and exonic sequences was performed and a polymorphism was found in the intron 7 .

PCR Primers:

Sense oligo: 5'AATGTGACTTCCACACCTCC 3' Antisense oligo: 5'GATGTCTGTCTGTCTGTGGA 3'

Polymorphism: The primers amplify two alleles A1 $=480$ and $\mathrm{A} 2=443 \mathrm{bp}$, which differ in one monomer element (37 bp).

Frequency: Estimated in 23 unrelated subjects

$\mathrm{A} 1=0.30$

$\mathrm{A} 2=0.70$

Chromosomal Localization: FVII gene has been localized to $13 \mathrm{q} 34$.

Mendelian Inheritance: Co-dominant segregation shown in seven families.

PCR Conditions: PCR amplifications are carried out in a volume of $25 \mu \mathrm{l}$, containing $0.1 \mu \mathrm{g}$ human DNA, 7 pmoles of each primer, $200 \mu \mathrm{M}$ dNTPs, $50 \mathrm{mM} \mathrm{KCl}, 10 \mathrm{mM}$ Tris-Cl $\mathrm{pH} 8.3$, $1.5 \mathrm{mM} \mathrm{MgCl}, 5 \%$ DMSO 1.6 units Taq polymerase. Cycles (30): $92^{\circ} \mathrm{C}$ for $20 \mathrm{sec}, 57^{\circ} \mathrm{C}$ for $3 \mathrm{sec}$ and $70^{\circ} \mathrm{C}$ for $40 \mathrm{sec}$. The products were electrophoresed on $2 \%$ agarose gel in $1 \times \mathrm{TAE}$ buffer.

Acknowledgements: This work was supported by Ric San Final Reg Emilia Romagna and by P.F. CNR Ing Genet $\mathbf{N}$ 9100021PF99.

References: 1) O'Hara,P.J., Grant,F.J., Haldeman,B.A., Gray,C.L., Insley,M.Y., Hagen,F.S. and Murray,M.J. (1987) Proc. Natl. Acad. Sci. USA 84, 5158-5162. 2) O'Hara,P.J. and Grant,F.J. (1988) Gene 66, 147-158.

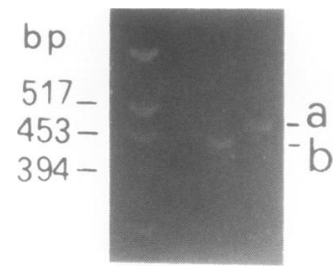

* To whom correspondence should be addressed 